\title{
ASPEK LINGKUNGAN INDUSTRI
}

Makalah Ini Disusun untuk Memenuhi Tugas pada Mata Kuliah Studi Kelayakan Bisnis

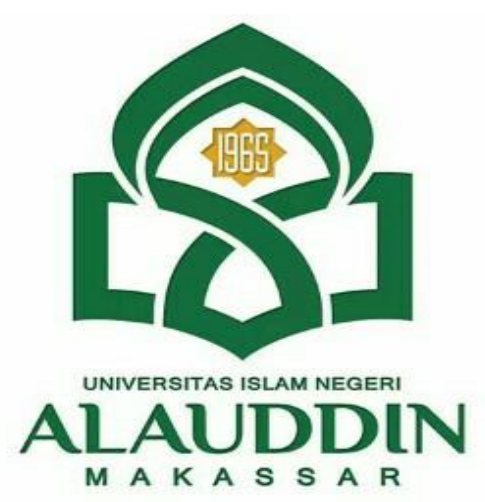

Kelompok 8

Muh. Akbar 90500120096

Widiyanti 90500120105

Rahmi 90500120121

Asrari 90500120124

PRODI PERBANKAN SYARIAH

FAKULTAS EKONOMI DAN BISNIS ISLAM UNIVERSITAS ISLAM NEGERI ALAUDDIN MAKASSAR 


\section{KATA PENGANTAR}

Puji syukur kehadirat Allah SWT yang telah memberikan rahmat dan hidayah-Nya sehingga kami dapat menyelesaikan tugas makalah yang berjudul "Aspek Lingkungan Industri” ini dengan tepat waktu. Adapun tujuan dari makalah ini adalah untuk memenuhi tugas pada mata kuliah Studi Kelayakan Bisnis. Selain itu, makalah ini bertujuan untuk menambah wawasan tentang Aspek Lingkungan Industri bagi para pembaca dan juga penulis.

Kami mengucapkan terima kasih kepada Bapak Supriadi, S.E.I., M.E.I, selaku dosen yang telah memberikan tugas ini sehingga dapat menambah pengetahuan dan wawasan sesuai bidang yang kami tekuni.

Makalah yang kami tulis ini masih jauh dari kata sempurna. Oleh karena itu, kritik dan saran yang membangun akan kami nantikan demi kesempurnaan makalah ini.

Toraja, 23 Sep 2021

Penulis 


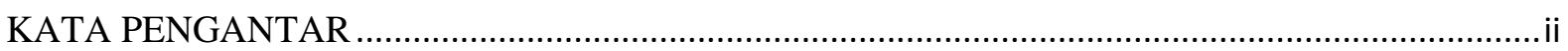

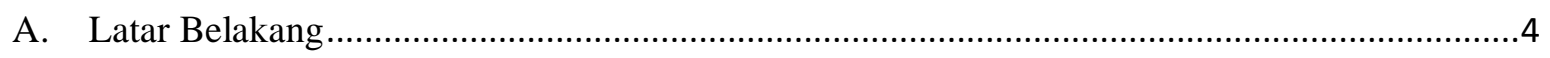

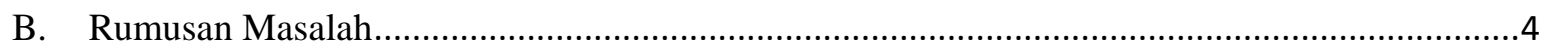

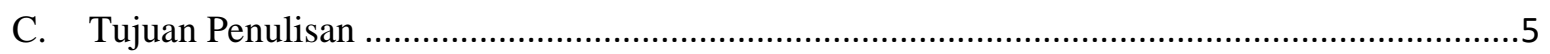

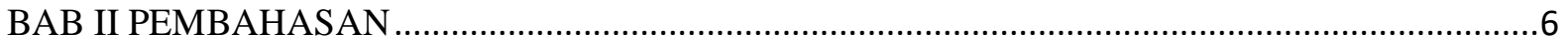

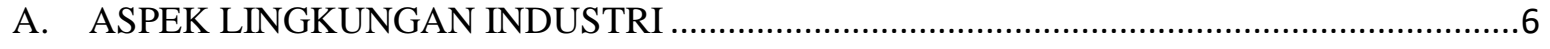

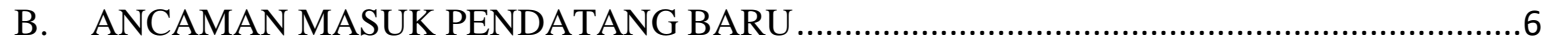

C. PERSAINGAN SESAMA PERUSAHAAN DALAM INDUSTRI........................................

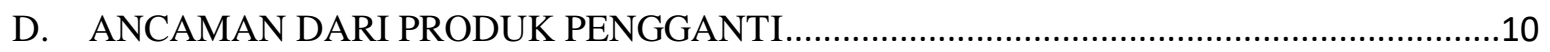

E. KEKUATAN TAWAR MENAWAR PEMBELI DAN PEMASOK. ….....................................10

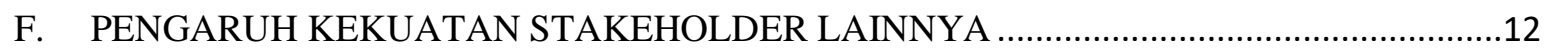

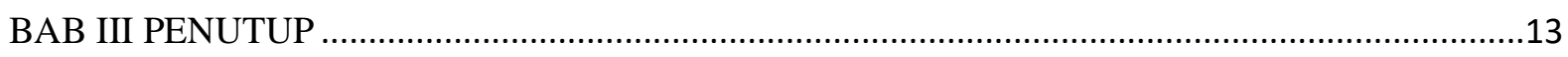

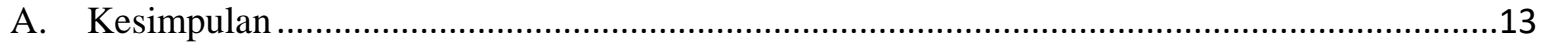

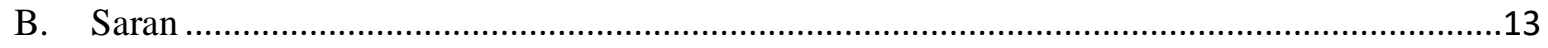

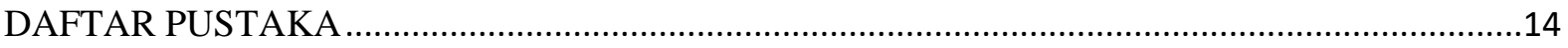




\section{BAB I \\ PENDAHULUAN}

\section{A. Latar Belakang}

Menurut Hitt, et.al (2001), Lingkungan Industri adalah serangkaian faktor-faktor ancaman dari pelaku bisnis baru, supplier, pembeli, produk pengganti, dan intensitas persaingan diantara para pesaing yang secara langsung mempengaruhi perusahaan dan tindakan serta tanggapan kompetitifnya.

Setiap perusahaan dipastikan berada dalam satu struktur industri persaingan yang memiliki karakteristik khusus yang berbeda dengan industri lainnya, terkecuali kalau perusahaan tersebut memang melakukan monopoli sehingga hanya ada satu perusahaan dalam satu industri. Jika hal

ini terjadi, maka aturan kompetisi industri adalah identik dengan strategi perusahaan monopoli itu sendiri.

Sebelum membahas tentang industri, yang perlu ditentukan adalah dari hasil penemuan ide usaha awal, industri seperti apa yang ingin kita masuki atau bisnis apa yang mau kita jalankan. Karena bisnis model awal ini, akan menentukan struktur kompetisi dengan pesaing di industri, pasar yang ingin kita masuki, strategi pemasaran apa yang kita pakai, kualitas produk yang akan kita produksi dan sumberdaya manusia yang akan kita pakai.

\section{B. Rumusan Masalah}

1. Bagaimana Aspek lingkungan industri?

2. Bagaimana ancaman masuk pendatang baru dalam industri ?

3. Bagaimana persaingan sesama perusahaan dalam industry?

4. Bagaimana ancaman dan produk pengganti ? 
5. Bagaimana kekukatan tawae menawar pembeli da pemasok ?

6. Bagaimana pengaruh kekuatan stakeholder lainnya ?

\section{Tujuan Penulisan}

1. Untuk mengetahui dan memahami bagaimana Aspek lingkungan industri ?

2. Untuk mengetahui dan memahami bagaimana ancaman masuk pendatang baru dalam industri?

3. Untuk mengetahui dan memahami bagaimana persaingan sesama perusahaan dalam industry?

4. Untuk mengetahui dan memahami bagaimana ancaman dan produk pengganti ?

5. Untuk menegtahui dan memahami bagaimana kekuatan tawar menawar pembeli dan pemasok ?

6. Untuk mengetahui dan memahami bagaimana pengaruh kekuatan stakeholder lainnya? 


\section{BAB II \\ PEMBAHASAN}

\section{A. ASPEK LINGKUNGAN INDUSTRI}

Aspek lingkungan industri lebih mengarah pada aspek persaingan dimana bisnis perusahaan berada. Akibatnya, faktor-faktor yang mempengaruhi kondisi persaingan, seperti ancaman pada perusahaan dan kekuatan yang dimiliki perusahaan termasuk kondisi persaingan itu sendiri menjadi perlu untuk dianalisis guna studi kelayakan bisnis. Tantangannya adalah untuk menempatkan suatu posisi dalam suatu industri dimana perusahaan dapat secara menguntungkan mempengaruhi faktor-faktor itu, atau dimana perusahaan itu dapat dengan sukses mempertahankan diri dari pengaruh-pengaruh mereka. Semakin besar kapasitas perusahaan untuk lebih mempengaruhi lingkungan industri, semakin besar kemungkinan perusahaan untuk menghasilkan laba di atas rata-rata.

Michael E.Porter mengemukakan konsep competitivestrategy yang menganalisis persaingan bisnis berdasarkan 5 aspek utama yang disebut Lima Kekuatan Bersaing. Lalu, R.E Freeman sebagaimana dikutip oleh Wheelen merekomendasikan aspek yang keenam untuk melengkapinya.

\section{B. ANCAMAN MASUK PENDATANG BARU}

Menurut Porter (1987) menyatakan bahwa ancaman masuknya pendatang baru ke dalam industri tergantung pada rintangan masuk yang ada, digabung dengan reaksi dari para pesaing yang ada, digabung dengan reaksi dari para pendatang baru. Jika rintangan atau hambatan ini besar dan/atau pendatang baru memperkirakan akan ada perlawanan yangt keras dari mka-muka lama, maka ancaman masuknya pendatang baru akan rendah. 
Masuknya perusahaan sebagai pendatang baru akan menimbulkan sejumlah implikasi bagi perusahaan yang sudah ada, misalnya kapasitas menjadi bertambah, terjadinya perebutan pangsa pasar serta perebutan sumber daya produksi yang terbatas.

Ada beberapa faktor penghambat pendatang baru masuk kedalam suatu industri yang sering disebut dengan Hambatan Masuk :

\section{a. Skala Ekonomi}

Apabila pendatang baru berproduksi dengan skala kecil, maka mereka akan dipaksa berproduksi pada biaya per unit yang tinggi padahal perusahaan yang ada tengah berupaya pada skala produksi yang terus diperbesar dan proses produksi yang terus menerus diefisienkan sehingga harga per unit barang menjadi lebih rendah.

b. Diferensiasi Produk

Diferensiasi yang menciptakan hambatan masuk memaksa pendatang baru untuk mengeluarkan biaya dan usaha yang besar untuk merebut para pelanggan yang loyal kepada perusahaan utama. Usaha besar itu misalnya adalah dengan iklan yang gencar dan pelayanan yang baik. Pada tahap awal, usaha-usaha ini membutuhkan biaya yang besar dan bahkan mendatangkan kerugian. Sering kali kondisi ini berjalan cukup lama.

\section{c. Kecukupan Modal}

Jenis industri yang memerlukan modal besar merupakan hambatan yang besar bagi pemain baru, terutama pada jenis industri yang memerlukan biaya yang besar untuk riset dan pengembangan serta eksplorasi.

d. Biaya Peralihan 
Hambatan masuk akan tercipta dengan adanya biaya peralihan pemasok, yaitu biaya yang harus dikeluarkan pembeli bilamana berpindah dari produk pemasok tertentu ke produk pemasok lainnya. Biaya peralihan ini dapat berupa biaya pelatihan kembali karyawan, biaya pelengkap yang baru, dan desain ulang produk. Pada akhirnya, biaya-biaya ini akan ditanggung oleh konsumennya. Apabila biaya peralihan yang diperlukan cukup besar, pesaing baru harus memberikan penawaran yang jauh lebih menarik terutama soal harga.

\section{e. Akses Kesaluran Distribusi}

Jalur distribusi sangat menentukan penyebaran produk. Perusahaan yang mempunyai jalur distribusi yang luas dan bekerja secara baik akan sangat menghambat masuknya produk baru kedalam pasar. Pendatang baru mungkin sulit memasuki saluran yang ada dan harus mengeluarkan biaya yang besar untuk membangun saluran sendiri.

\section{f. Ketidakunggulan Biaya Independen}

Keunggulan biaya yang dipunyai oleh perusahaan yang sudah ada sulit ditiru oleh pendatang baru. Keunggulan itu mungkin timbul dari teknologi yang telah dipatenkan perusahaan, konsensi bahan baku, atau subsudi pemerintah.

\section{g. Peraturan Pemerintah}

Pemerintah biasanya menerbitkan sejumlah aturan yang mengatur bidang- bidang tertentu seperti yang selalu diterbitkan oleh pemerintah Indonesia, misalnya lewat Daftra Investasi Negatif (DIN). Peraturan pemerintah dapat menimbulkan hambatan masuk bagi pendatang baru. 


\section{PERSAINGAN SESAMA PERUSAHAAN DALAM INDUSTRI}

Persaingan dalam industri sangat mempengaruhi kebijakan dan kinerja perusahaan. Dalam situasi persaingan yang oligopoli, perusahaan mempunyai kekuatan yang cukup besar untuk mempengaruhi pasar. Persaingan pasar yang sempurna biasanya akan memaksa perusahaan menjadi follower termasuk dalam hal harga produk. Menurut Porter, tingkat persaingan dipengaruhi beberapa faktor, yaitu:

\section{Jumlah Kompetitor}

Jumlah kompetitor atau pesaing sudah tentu akan mempengaruhi tingkat persaingan. Kompetitor hendaknya dilihat dari beberapa sisi, seperti jumlah, ukuran, dan kekuatannya.

\section{Tingkat Pertumbuhan Industri}

Pertumbuhan industri yang besar biasanya menyediakan sejumlah peluang bagi perusahaan untuk tumbuh bersama industrinya. Pertumbuhan industri yang lambat sebaiknya tidak direspon dengan ekspansi pasar kecuali peusahaan mampu mengambil pangsa pasar pesaing. Kondisi ini dapat menimbulkan trend penurunan harga atau terjadinya perang harga.

\section{Karakteristik Produk}

Produk hendaknya tidak hanya sekedar menyediakan kebutuhan dasar akan tetapi hendaknya memiliki suatu pembedaan (differentiation) atau nilai tambah.

\section{Biaya Tetap ysng Besar}

Pada jenis industri yang mempunyai total biaya tetap yang besar, perusahaan hendaknya beroperasi pada skala ekonomi yang tinggi. Akibatnya, perusahaan kadang kala terpaksa menjual produk dibawah biaya produksi. 


\section{Kapasitas}

Kapasitas selalu berkorelasi dengan biaya produk per unit. Produksi pada kapasitas yang tinggi diperlukan untuk menjaga efisiensi biaya per unit. Penambahan fasilitas produksi dapat dilakukan apabila perusahaan telah mampu berproduksi pada tingkat maksimal.

\section{Hambatan Keluar}

Hambatan keluar memaksa perusahaan untuk tidak keluar dari imdustri. Hambatan ini dapat berupa aset-aset khusus ataupun kesetiaan manajemen pada bisnis tersebut. Contohnya adalah idealisme dalam bisnis. Dalam kondisi demikian, perusahaan biasanya akan berusaha bertahan dan menghindari kerugian yang besar sambil menunggu waktu yang tepat untuk keluar.

\section{ANCAMAN DARI PRODUK PENGGANTI}

Perusahaan-perusahaan yang berada dalam suatu industri bersaing pula dengan produk pengganti. Walaupun karakteristiknya berbeda, barang substitusi dapat memberikan fungsi atau jasa yang sama. Ancaman produk substitusi adalah kuat bilamana konsumen dihadapkan pada sedikitnya switchingcost dan jika produk substitusi itu mempunyai harga yang lebih murah atau kualitasnya sama, bahkan lebih tinggi daripada produk-produk suatu industri.

\section{E. KEKUATAN TAWAR MENAWAR PEMBELI DAN PEMASOK. 1. KEKUATAN TAWAR MENAWAR PEMBELI.}

Pembeli mampu mempengaruhi perusahaan untuk memotong harga, meningkatkan mutu dan pelayanan serta mengadu perusahaan dengan kompetitor melalui kekuatan yang mereka miliki.

Beberapa kondisi yang mungkin dihadapi perusahaan antara lain adalah: 
- Pembeli membeli dalam jumlah yang besar.

- Pembeli mampu memproduksi produk yang diperlukan.

- Sifat produk tidak terdiferensiasi dan banyak pemasok.

- Switchingcost pemasok adalah kecil.

- Produk yang dibeli perusahaan mempunyai andil presentase yang besar bagi biaya produksi pembeli, sehingga pembeli akan menawarkan insentif kepada pegawainya yang mampu menyediakan produk yang sama dengan harga yang lebih murah.

- Pembeli mempunyai tingkat profitabilitas yang rendah sehingga sensitif terhadap harga dan diferensiasi servis.

- Produk perusahaan tidak terlalu penting bagi pembeli, sehingga pembeli dengan mudah mencari substitusinya.

\section{KEKUATAN TAWAR MENAWAR PEMASOK (SUPPLIERS)}

Pemasok dapat mempengaruhi industri lewat kemampuan mereka menaikan harga atau megurangi kualitas produk atau servis. Pemasok akan kuat apabila beberapa kondisi berikut terpenuhi:

- Jumlah pemasok sedikit.

- Produk/pelayanan yang ada adalah unik dan mampu menciptakan switching cost yang besar.

- Tidak tersedia produk substitusi.

- Pemasok mampu melakukan integrasi kedepan dan mengolah produk yang dihasilkan menjadi produk yang sama yang dihasilkan perusahaan.

- Perusahaan hanya membeli dalam jumlah yang kecil dari pemasok. 


\section{F. PENGARUH KEKUATAN STAKEHOLDER LAINNYA}

Kekuatan keenam yang ditambahkan oleh Freeman yang dikutip Wheelen adalah berupa kekuatan diluar perusahaan yang mempunyai pengaruh dan kepentingan secara langsung kepada perusahaan. Stakeholder yang dimaksud antara lain adalah pemerintah, serikat pekerja, lingkungan masyarakat, kreditor, pemasok, asosiasi dagang, kelompok yang mempunyai kepentingan lain, dan pemegang saham. Pengaruh dari masing-masing stakeholder adalah bervariasi di antara industri yang satu dengan yang lain.

Pentingnya peran stakeholder terhadap perusahaan membuat perusahaan perlu melakukan analisis stakeholder. Mitchell, Agle, dan Wood (1997) dalam Clement (2005) menyatakan bahwa terdapat tiga karasteristik yang menunjukkan seberapa penting suatu stakeholder bagi perusahaan, yaitu kekuatan (power), urgensi (urgency), dan hak kekuasaan (legitimacy). Suatu stakeholder dianggap mempunyai kekuatan ketika dapat memaksakan kehendaknya dalam hubungan dengan perusahaan. Di sisi lain, urgensi menunjukkan seberapa cepat perusahaan perlu berupaya terkait dengan permintaan atau tindakan stakeholder. Sedangkan stakeholder memiliki legitimasi ketika tindakannya terhadap perusahaan secara luas dianggap sesuai dengan norma. 


\section{BAB III}

\section{PENUTUP}

\section{A. Kesimpulan}

Dalam aspek industri diperlukan beberapa analisa yang meliputi persaingan industri yang saat ini, kekuatan dan penawaran pemebeli terhadap produk, bentuk barang subtitusi yang bisa menggantikan produk, kekuatan supplier dalam industri, kemampuan pesaing baru untuk masuk dengan menawarkan produk yang sejenis. Dalam aspek lingkungan industri ada beberapa aspek yang perlu dikaji yaitu :

- Persaingan sesama perusahaan dalam industrinya

- Ancaman dari produk pengganti

- Kekuatan tawa menawar pembeli dan pemasok

- Pengaruh kekuatan stakeholder lainnya.

\section{B. Saran}

Sangat diharapkan kepada pembaca agar tetap mencari sumber-sumber bacaan lainnya, agar tidak hanya berfokus pada makalah ini saja. Karena makalah ini masih sangat banyak kekurangan. Untuk itu kritik dan saran sangat kami butuhkan. 


\section{DAFTAR PUSTAKA}

Heodi Prasetyo, W. S. (2018). Industri 4.0: Telaah Klarifikasi Aspek Dan Arah Perkembangan Riset. Jurnal Teknik Industri , 13 (1), 17-26.

Mochammad Biodi, B. S. (2017). Analisis Lingkungan Industri Guna Menentkan Business Strategy Dalam Rangka Mencapai Keunggulan Bersaing. Jurnal Administrasi Bisnis , 50 (2), 172-181.

Nurseto, S. (2012). Analisis Pengaruh Lingkungan Industri Terhadap Strategi Pemasaran Dan Dampaknya Terhadap Kinerja Pemasaran. Jurnal Administrasi Bisnis , 1 (1), 72-83.

Sherly Dwi Fedora, R. F. (2019). Analisis Pemangku Kepentingan (Stakeholder) Pada Unit Hubungan Masyarakat (HUMAS) Dan Kesekretariatan PT Semen Padang. Jurnal Administrasi Bisnis , 2 (1), 12-38.

Teguh Dwi Mena, d. (2019). Kajian Dampak Lingkungan Industri Terhadap Kualitas Hidup Warga Sekitar. Jurnal Kesehatan Masyarakat , 7 (1), 156-171. 